\title{
A new HCV mouse model on the block
}

\author{
Cell Research (2014) 24:1153-1154. doi:10.1038/cr.2014.126; published online 26 September 2014
}

The investigation of virus-induced liver disease and hepatocellular carcinoma needs small animal models modeling hepatitis $\mathrm{C}$ virus (HCV) infection and liver disease biology. A recent study published in Cell Research reports a novel mouse model which is permissive for chronic $\mathrm{HCV}$ infection and shows chronic liver injury including inflammation, steatosis and fibrosis.

Chronic hepatitis $\mathrm{C}$ virus (HCV) infection is a major cause of liver disease worldwide. The development of directacting antivirals has revolutionized treatment by offering cure [1]. However, several hurdles remain. High costs limit treatment access in the majority of patients. Infection is often diagnosed at a late stage when advanced liver disease and cancer are established. Cure in advanced liver disease does not eliminate the risk of hepatocellular carcinoma (HCC). Re-infection remains possible and a vaccine is not available [2].

To better understand the pathogenesis of virus-induced liver disease and HCC, a small animal model permissive for $\mathrm{HCV}$ infection and modeling liver disease biology is needed [3]. HCV infection is limited to humans and chimpanzees, predominantly due to distinct host-dependency factors and innate antiviral immune responses precluding cross-infection of other species [4]. Research efforts have focused on humanizing mice permissive to $\mathrm{HCV}$ infection. This has led to the development of conceptually three different types of mouse models.

The human liver chimeric mouse is based on immune- and hepato-deficient mice repopulated with human hepa- tocytes. While the uPA-SCID [5] and FRG [6] models are extremely useful to study the viral life cycle and antivirals, the lack of an adaptive immune system and liver disease precludes the use for the study of liver disease biology and vaccine evaluation (Table 1 ). In the AFC8-huHSC/Hep model [7] based on modified Rag $_{-2^{-/}}$mice, activation of the overexpressed FK506-binding protein and caspase- 8 fusion protein in the liver induces death of mouse hepatocytes and facilitates engraftment of human hepatocyte progenitor and $\mathrm{CD}_{3} 4^{+}$haematopoetic stem cells. While infected mice exhibit liver inflammation and fibrosis, this model appears to be limited with detection of virus only in the liver (Table 1). Later, immunocompetent transgenic mice expressing the four main human entry factors (4hEF) namely CD81, scavenger receptor BI (SR-BI), claudin 1 (CLDN1) and OCLN were developed [8]. Sustained and robust HCV infection for 90 days was achieved by crossing the 4hEF mice with mice knocked out for STAT1 [9]. Furthermore, HCV infection in these mice elicited antiviral cellular and humoral immune responses. Although the animals were not reported to develop liver disease, this robust model represents a major breakthrough since it allows for studying HCV-induced immune responses and the preclinical evaluation of vaccine candidates in a small animal model (Table 1).

Complementing these achievements, a recent study published in Cell Research by Chen et al. [10] reports an immunocompetent animal model permissive for $\mathrm{HCV}$ infection and evidence for liver disease (Table 1). The authors describe the creation of transgenic mice expressing human occludin (OCLN) and CD81 in an outbred ICR (CD-1) background $(\mathrm{C} / \mathrm{OTg})$. The mice were permissive to low-level infection with serum- and cell culture-derived HCV and maintained stable level of $\mathrm{HCV}$ RNA in serum and in the liver for over 12 months. In situ hybridization of HCV RNA and staining of HCV NS5A protein in the liver cells of mice at different time points confirmed sustained infection. Moreover, an HCV protease inhibitor cured the infection. The production of infectious viruses was further confirmed by successful infection of Huh7.5.1 cells with mouse sera and successful passage of $\mathrm{HCV}$ into naïve $\mathrm{C} / \mathrm{OTg}$ mice.

Albeit liver function remained normal (as indicated by unchanged ALT levels), the authors observed moderate hepatic inflammation in some of the persistently infected $\mathrm{C} / \mathrm{OTg}$ mice as scored by Knodell histological activities in H\&E staining. Moreover, both $\mathrm{H} \& \mathrm{E}$ and Oil Red staining showed that micro- or macro-vesicular steatotic areas increased in infected mice. Three persistently infected animals showed evidence for fibrosis and one animal exhibited early stage of cirrhosis. Evidence for neoplastic lesions was not observed [10].

In the previous report by Dorner et al. [9], overexpressing human CD81 and OCLN in mice with STAT1 deficiency demonstrated sustained HCV infection for $\sim 90$ days as against 12 months with ICR mice without obvious immune deficiency. To better understand the mechanisms for persistent infection in the new model, the $\mathrm{C} / \mathrm{OTg}$ mice were backcrossed to $\mathrm{C} 57 \mathrm{BL} / 6$ background 
Table 1 Mouse models permissive for $\mathrm{HCV}$ infection.

\begin{tabular}{|c|c|c|c|c|}
\hline & $\begin{array}{l}\text { Human liver } \\
\text { chimeric } \\
\text { uPA/SCID, } \\
\text { FRG }\end{array}$ & AFC8-huHSC/Hep & $\begin{array}{l}\text { Humanized } \\
\text { transgenic } \\
\text { Rosa26-Fluc }\end{array}$ & $\mathrm{C} / \mathrm{O}^{\mathrm{Tg}}$ \\
\hline References & {$[5,6]$} & [7] & {$[8,9]$} & {$[10]$} \\
\hline Strain background & BalbC & BalbC & $\mathrm{C} 57 \mathrm{BL} / 6$ & ICR \\
\hline Concept & $\begin{array}{l}\text { Immuno- and } \\
\text { hepatodeficient } \\
\text { mice repopulated } \\
\text { with human } \\
\text { hepatocytes }\end{array}$ & $\begin{array}{l}\text { Immuno- and } \\
\text { hepatodeficient mice } \\
\text { repopulated with } \\
\text { human progenitor cells }\end{array}$ & $\begin{array}{l}\text { Humanized for } \\
\text { CD81, SR-BI, } \\
\text { CLDN1 and } \\
\text { OCLN; deficient in } \\
\text { STAT1 }\end{array}$ & $\begin{array}{l}\text { Humanized for } \\
\text { CD81 and OCLN; } \\
\text { Modified } \\
\text { host-dependency } \\
\text { factor and ISG } \\
\text { expression }\end{array}$ \\
\hline Inoculum & Serum, HCVcc & Serum & $\mathrm{HCV} c \mathrm{C}$ & Serum, HCV cc \\
\hline Chronic infection & $>6$ months & 3 months & 3 months & $>12$ months \\
\hline $\begin{array}{l}\text { Viral load: serum } \\
\text { (copies/ml) }\end{array}$ & $10^{6}-10^{7}$ & Not reported & $10^{4}-10^{5}$ & $10^{2}-10^{4}$ \\
\hline Viral load: liver & $\sim 10^{6 *}$ & $10^{4}-10^{5 *}$ & $10^{2}-10^{3 *}$ & $10^{3}-10^{4 * *}$ \\
\hline $\begin{array}{l}\text { Adaptive immune } \\
\text { system }\end{array}$ & Absent & Human & Mouse & Mouse \\
\hline $\begin{array}{l}\text { Anti-HCV B cell } \\
\text { responses }\end{array}$ & Absent & Not reported & Yes & Not reported \\
\hline $\begin{array}{l}\text { Anti-HCV T cell } \\
\text { responses }\end{array}$ & Absent & Yes & Yes & Not reported \\
\hline $\begin{array}{l}\text { Evidence for HCV } \\
\text { associated human } \\
\text { liver disease }\end{array}$ & Absent & Inflammation, fibrosis & Not reported & $\begin{array}{l}\text { Inflammation, } \\
\text { steatosis, fibrosis }\end{array}$ \\
\hline
\end{tabular}

Characteristics of $\mathrm{HCV}$ infection, adaptive immune responses and occurrence of liver disease in HCV-permissive mouse models are listed. SR-BI, scavenger receptor class B type I; CLDN1, claudin-1; OCLN, occludin; HCVcc, cell culture-derived HCV. * ${ }^{*}$ copies/ $\mu$ g total RNA; **copies/mg liver tissue)

to yield B6-C/OTg mice. Surprisingly, the B6-C/OTg mice did not support sustained $\mathrm{HCV}$ infection, indicating a potential functional role of genetic background in establishing chronic HCV infection [10]. Further investigations revealed significantly higher levels of apoE expression and progressive increase in miR-122 levels during the course of infection in $\mathrm{C} / \mathrm{OTg}$ mice as compared to $\mathrm{B} 6-\mathrm{C} / \mathrm{OTg}$. In addition, the C/OTg mice showed transiently downregulated expression of anti-HCV interferon-stimulated genes (ISGs), namely ifi44 and Eif2ak2, unlike B6-C/ OTg mice, in the first 2 weeks post infection. Furthermore, using transgenic

technology the authors demonstrated that co-expression of both OCLN and CD81 was required for susceptibility to $\mathrm{HCV}$ infection. Based on these results, the authors conclude that the altered expression of defined host-dependency factors combined with different innate immune responses against $\mathrm{HCV}$ infection facilitates the establishment of $\mathrm{HCV}$ infection in this particular host background.

Taken together, this study provides a novel immunocompetent $\mathrm{HCV}$ mouse model with evidence for $\mathrm{HCV}$-associated liver diseases. The observation of liver disease in infected animals is interesting and of significant impact since it may allow the study of virusinduced liver injury including inflammation, steatosis and fibrosis - an urgent unmet need in the field. Further studies are needed to study the causal relationship between $\mathrm{HCV}$, inflammation and antiviral immune responses and liver disease in this model. A potential challenge could be the lower viral load compared to other models and human blood - adaptation of viral strains to this model or further engineering of host-dependency factor expression in the mouse liver could overcome this limitation. Finally, a detailed characterization of antiviral immune responses may help to study whether this model will also be useful for vaccine development - another challenge in $\mathrm{HCV}$ translational research.

Rajiv G Tawar ${ }^{1,2}$, Laurent Mailly ${ }^{1,2}$, Thomas F Baumert ${ }^{1,2,3}$

${ }^{1}$ Inserm, U1110, Strasbourg, France, ${ }^{2}$ Université de Strasbourg, Strasbourg, France, ${ }^{3}$ Pôle Hépato-digestif, Institut Hospitalo-Universitaire, Strasbourg, France

Correspondence: Thomas F Baumert

Tel: +33 3688537 03; Fax: +33 368853750

E-mail: Thomas.Baumert@unistra.fr

\section{References}

1 Chung RT, Baumert TF. N Engl J Med 2014; 370:1576-1578.

2 Baumert TF, Fauvelle C, Chen D, et al. J Hepatol 2014; in press

3 Mailly L, Robinet E, Meuleman P, et al. Front Microbiol 2013; 4:213.

4 Sandmann L, Ploss A. Virology 2013; 435:70-80.

5 Mercer DF, Schiller DE, Elliott JF, et al. Nat Med 2001; 7:927-933.

6 Bissig KD, Wieland SF, Tran P, et al. J Clin Invest 2010; 120:924-930.

7 Washburn ML, Bility MT, Zhang L, et al. Gastroenterology 2011; 140:1334-1344.

8 Dorner M, Horwitz JA, Robbins JB, et al. Nature 2011; 474:208-211.

9 Dorner M, Horwitz JA, Donovan BM, et al. Nature 2013; 501:237-241.

10 Chen J, Zhao Y, Zhang C, et al. Cell Res 2014; 24:1050-1066. 